\title{
Nest-site preference of Hooded Crow (Corvus cornix L.) in Debrecen, Hungary
}

\author{
László Kövér - Lajos Juhász - Péter Gyüre \\ University of Debrecen, Faculty of Agricultural and Food Sciences and Environmental Management, \\ Department of Nature Conservation Zoology and Game Management \\ koverl@agr.unideb.hu
}

Keywords: Hooded Crow, Corvus cornix, nest site preference, urban ecology, Debrecen

\section{SUMMARY}

In the past decade, the population of the Hooded Crow has shown significant growth in Debrecen, Hungary. The aim of this study was to become acquainted with the nest-site selection behavior of Hooded Crows in urban spaces. While our research revealed that the Hooded Crow is not particular when it comes to selecting among tree species for nesting, we did notice differences regarding nesting height. Hooded Crows living in the city build their nests higher up than those living outside Debrecen's city limits. We also discovered a slight, insignificant difference between nesting heights and tree species, which is probably due to the different characteristics of the given tree species. As for nesting heights, we found that in typical urban habitats there were no relevant differences. However, when we compared these habitats in pairs, it came to light that nesting heights -when comparing solitary trees - wood segments and tree rows - wooded segments- did show significant differences, which can be explained by the various conditions provided by the habitats mentioned.

In summary, the following results emerged from our research:

1. The Hooded Crow prefers approximately the same nesting heights in all kinds of habitats, urban environment and tree species.

2. The nesting height does not significantly depend on the habitat itself or on the tree species.

\section{INTRODUCTION}

\section{The urbanization of the Hooded Crow}

The urbanization of birds is concurrent with the development of civilization. This process is an active and expansive phenomenon. A city may be considered to be an independent ecosystem due to the characteristic species dwelling within a given city (Davis \& Glick 1978, Bezzel 1985, Parlange 1998). The composition of species is determined by biotic and abiotic factors (Böhning-Gaese 1997, Roy et al. 1999).

The appearance of the Hooded Crow has been observed in many European countries since 1960. Many studies tell about the crow's settlement and continuous population increase; for example: in Hungary (Tapfer 1974, 1978, 1985, Juhász 1983, Fintha 1994, Ujhelyi 2005, Kövér \& Juhász 2008), in Finland (Hugg 1994, Vuorisalo et al. 2003), in Norway (Munkejord et al. 1985, Parker 1985), in Poland (Mazgajski et al. 2008), in Russia (Konstantinov et al. 1982, Korbut, 1996). There are several factors driving this species' urbanization. Primarily there are the possibilities provided in urban settings for nesting and diverse sources of food (Kalotás 1995, Bedő \& Heltai 2003, Vuorisalo et al., 2003). In addition, cities provide defenses against predators (Kalotás 1995, Vuorisalo et al. 2003). In local cases, disturbances by man, including intense game management activities, would be influential factors, as well (Sorace 2001, Withey \& Marzluff 2005). Last, but not least, Hooded Crows are highly intelligent and ecologically flexible (Konstantinov et al. 1982, Ilyichev et al. 1990; Von Busche 2001), and these traits led them to adopt the excellent habitat cities provide.

As a nesting species, we note the appearance of the Hooded Crow in Debrecen in 1959, when one pair hatched in the botanical garden (Juhász 1983). Afterwards, the species "disappeared" for twenty years, only nesting here again in 1972 (Fintha 1994), and again in 1979 (Juhász 1983). Since the 1980s, we have witnessed their continuous population increase in the city. An example includes their appearance in the city cemetery, as well (Juhász 1999). At present, the Hooded Crow is a permanent, common breeding species in Debrecen, observable in all parts of town (Juhász et al. 2009).

\section{The nesting habit of the Hooded Crow}

The Hooded Crow is a typical solitary nesting species, with a stable territorial system maintained year by year (Hewson \& Leitch 1982, Smedshaug et al. 2002). Pairs appear at their nest-sites as early as February and they begin to build their nests soon thereafter. The species is not particular when it comes to selecting the species of tree for nesting; the bearing ability of its branches and the protective functions of each tree are the criteria for selection. Faragó (2002) found nests in Acer campestre, Carpinus betulus, Pyrus pyraster, Morus alba Salix sp., Alnus sp., Fraxinus sp. Tapfer (1985) mentioned nests in Aesculus hippocastanum in an urban environment. Havasi (1993) has identified nests in Prunus spinosa, as well. Juhász et al. (2009) wrote about nesting in 12 species (Quercus robur, Pinus silvestris, Pinus nigra, Sophora japonica, Celtic occidentalis, Robinia pseudoacacia, Platanus hybrida, Ulmus pumila celer, Acer saccharinum, Gleditsia triacanthos, Maclura pomifera, Populus alba) in an urban environment. The Hooded Crow builds its nests in the upper third of the 
crown of s tree. In the placing of its nest, a crow prefers a southeast direction, because the nest is thus protected from the western winds and enjoys the southern sun at the same time (Moller 1981). Faragó (2002) determined the average nest height at 6.4 meters $(3-13 \mathrm{~m})(\mathrm{n}=45)$ on areas outside Hungarian cities. Hooded Crows build nests up to 3-4 meters in cases of less disturbed areas (Havasi, 1993). Ternovác (1983) reported on a pair of Hooded Crows nesting on the ground. Recently, observations about nesting on high-voltage pylons have become more common (Ujhelyi 2005). In areas outside city limits, mean nesting heights were noted at 9 meters in Sweden (Loman 1975), 14.5 meters (Kulczycki 1973) and 9.9 meters in Poland (Zduniak \& Kuczynski 2003), 12.6 meters in Germany (Abshagen 1963) and 9.9 meters in Finland (Tenovuo, 1963). The nesting of Hooded Crow in urban areas was thoroughly researched in Finland. In Turku, depending on the habitat type, 1.4-25.5 nests $/ \mathrm{km}^{2}$ were determined (Hugg 1994), while in Helsinki, this figure numbered 18.4 nests $/ \mathrm{km}^{2}$ (Vuorisalo et al. 2003).

\section{MATERIALS AND METHODS}

We researched the nest-site selection of the Hooded Crow in an urban environment (Debrecen, Hungary) from 2006 to 2010. We located active nests, mainly in the north part of the city, because of the nesting and feeding possibilities in this area of town, i.e. $16 \mathrm{~km}^{2}$, in every spring of each of the given years. For each active nest $(\mathrm{n}=102)$, we described the habitat (single tree, tree row, park, wooded segment) and noted the tree species and height of the nest. We used laser distance-meter (TruPulse 200) in order to measure the nest height. We recorded the GPS coordinate of every nest (Garmin GPSMap $60 \mathrm{CSx}$ ). For evaluation of the data, we used Kurskal-Wallis and Mann-Whitney U tests and correlation analysis.

\section{RESULTS}

During the 5 years of examinations, we localized 102 inhabited nests in 13 different tree species (Quercus robur, Quercus rubra, Pinus silvestris, Pinus nigra, Sophora japonica, Celtic occidentalis, Robinia pseudoacacia, Platanus hybrida, Ulmus pumila celer, Acer saccharinum, Gleditsia triacanthos, Maclura pomifera, Populus alba). Nest density has grown year by year (2006: 0,68 nest $/ \mathrm{km}^{2}, 2007: 0,75 \mathrm{nest} / \mathrm{km}^{2}, 2008$ : 1,5 nest $/ \mathrm{km}^{2}$, 2009: 1,56 nest $\left./ \mathrm{km}^{2}, 2010: 1,88 \mathrm{nest} / \mathrm{km}^{2}\right)\left(\mathrm{R}^{2}=0,9139\right)$. According to our observations, crows build new nests every year, and show no tendency to rebuild or renovate previously used nests. Nesting height was between 12-21 meters, with an average of 16.22 meters (Table 1).

The range of the nest height of Hooded Crow (Corvus cornix) $(\mathrm{n}=102)$

\begin{tabular}{|c|c|c|}
\hline Height (m) & Frequency & $\%$ \\
\hline 12 & 6 & 5,9 \\
\hline 13 & 6 & 5,9 \\
\hline 14 & 17 & 16,7 \\
\hline 15 & 13 & 12,7 \\
\hline 16 & 14 & 13,7 \\
\hline 17 & 14 & 13,7 \\
\hline 18 & 11 & 10,8 \\
\hline 19 & 12 & 11,8 \\
\hline 20 & 6 & 5,9 \\
\hline 21 & 3 & 2,9 \\
\hline Total: & 102 & 100 \\
\hline $\begin{array}{l}\text { Mean: 16.22 } \\
\text { Deviation: } 2.36 \\
\end{array}$ & & \\
\hline
\end{tabular}

We compared nest height with the tree species (Figure 1), and found a slight but insignificant difference (Kruskal-Wallis test, $\mathrm{H}=21,357, \mathrm{df}=13, \mathrm{p}=0.045)$. In the case of Quercus robur a considerable number $(75.86 \%$, $\mathrm{n}=29$ ) of crows built their nests in the roots of Loranthus europaeus. 
Figure 1. The nesting height of Hooded Crow (Corvus cornix) in different tree species (n=102)

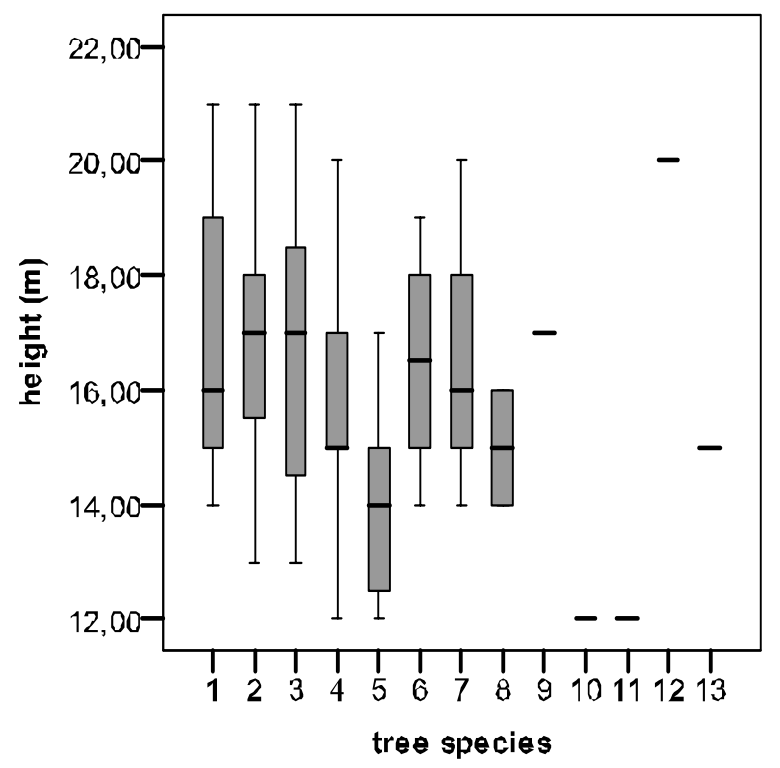

\begin{tabular}{|lll|}
\hline 1: & Quercus robur & $\mathrm{n}=29$ \\
2: & Pinus silvestris & $\mathrm{n}=19$ \\
3: & Sophora japonica & $\mathrm{n}=16$ \\
4: & Celtic occidentalis & $\mathrm{n}=13$ \\
5: & Pinus nigra & $\mathrm{n}=7$ \\
6: & Robinia pseudoacacia & $\mathrm{n}=6$ \\
7: & Platanus hybrida & $\mathrm{n}=3$ \\
8: & Ulmus pumila celer & $\mathrm{n}=2$ \\
9: & Acer saccharinum & $\mathrm{n}=2$ \\
10: & Gleditsia triacanthos & $\mathrm{n}=2$ \\
11: & Maclura pomifera & $\mathrm{n}=1$ \\
12: & Populus alba & $\mathrm{n}=1$ \\
13: & Quercus rubra & $\mathrm{n}=1$ \\
\hline \multicolumn{4}{|c|}{} & $\mathrm{t}: 102$ \\
\hline
\end{tabular}

Nest height was also compared with different categories of habitats (Figure 2). After examining the nesting heights of Hooded Crows, the results revealed no important difference between habitats (Kruskal-Wallis test, $\mathrm{H}=3,559, \mathrm{df}=3, \mathrm{p}=0,313)$. However, when these habitats were compared in pairs, in two cases: single tree-wood segments (Mann-Whittney $U$ test, $U=58,500, Z=-0,565, p=0,588$ ) and tree rows-wooded segments (MannWhittney $U$ test, $\mathrm{U}=109,500, \mathrm{Z}=-0,242, \mathrm{p}=0,814$ ) we found a significant discrepancy.

Figure 2. The nesting height of Hooded Crow (Corvus cornix) in different habitats (n=102)

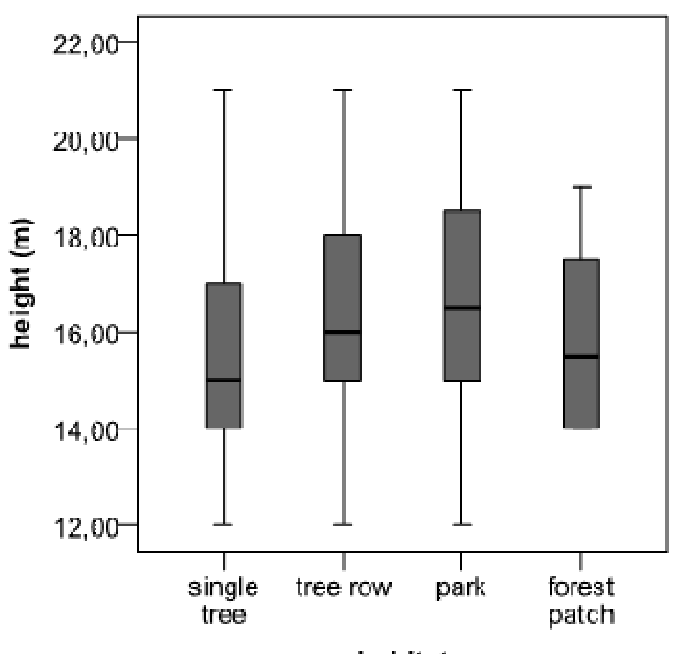

\section{DISCUSSION}

In the past decade, Hooded Crows have showed an intense move towards urbanization in Debrecen. Various factors may be driving this phenomenon, including the nesting possibilities in towns, which is one of the key factors of settlement. Crows living in urban environments are not particular in selecting among tree species, as is proven by the 13 species described above. Nest density has grown year by year $\left(\mathrm{R}^{2}=0.9139\right)$, which means that the city's capacity to support Hooded Crows has not reached its maximum yet. As a consequence, the population of this species is expected to grow further, as is confirmed by Finnish researchers, who have recorded data containing much larger numbers (Hugg 1994, Vuorisalo et al. 2003). Average nest height was 16.22 meters (12$21 \mathrm{~m})(\mathrm{n}=102)$ which is higher than data collected in areas outside the city, where Faragó (2002) measured an average of 6.4 meters $(3-13 \mathrm{~m})$. Building nests at a higher altitude may be due to anthropogenic disturbance. Altitude is the most important element of choosing a nest- which is why nests are built in the highest possible areas. As mentioned previously, in the case of Quercus robur $(75.86 \%, \mathrm{n}=29)$, many crows tend to build their nests in the roots of Loranthus europaeus, which can be explained by this tree's ability to provide greater safety 
and better possibilities for concealment. Our data showed a slight, insignificant difference between nesting heights and tree species, which is probably due to the different characteristics of the given tree species.

Our data regarding nesting heights shows that, in typical urban habitats, there are no relevant differences. However, when habitats are compared in pairs, when comparing single trees with wood segments and tree rows with wood segments, nesting heights show significant differences, which can be explained by the various conditions provided by the habitats we mentioned.

To sum up, the Hooded Crow in urban environments prefers approximately the same nesting height in all kinds of habitats and tree species, and nesting height does not significantly depend on the habitat itself or on the tree species.

\section{REFERENCES}

Abshagen, K. 1963.Über die Nester der Nebelkrähen, Corvus corone cornix. Bietr. Vogelk, 8: 325-338.

Bedő, P.-Heltai, M. (2003): A dolmányos és a vetési varjú állományok helyzete Magyarországon. Vadbiológia, 10: 98-106.

Bezzel, E. (1985): Birdlife in intensively used rural and urban environments. Ornis Fennica, 62: 90-95.

Böhning-Gaese, K. (1997): Determinants of avian species richness at different spatial scales. Journal of Biogeography, $24: 49-60$.

Davis, A.M.-Glick, T.F. (1978): Urban ecosystems and island biogeography. Environmental Conservation, 5: $299-304$.

Faragó, S. (2002):Vadászati állattan. Mezőgazda kiadó, Budapest. 496 p.

Fintha, I. (1994): A dolmányos varjú (Corvus cornix) életformájának átalakulása az utóbbi években. Madártani tájékoztató, 7-12: 23-24.

Havasi, L. (1993): Dolmányos varjú (Corvus cornix) különös fészkelése. Madártani tájékoztató, 1-6: 44.

Hewson, R.-Leitch, A.F. (1982): The spacing and density of hooded crow in Agryll (Strathclyde) (Corvus corone). Bird Study, 29/3: 235238.

Hugg, T. (1994): Nest defense behaviour and reproductive success of the hooded crow in urban environments. MSc Thesis, University of Turku.

Ilyichev, V.D.-Konstantinov, V.M.-Zvonov, B.M. (1990): The urbanized landscape as an arena for mutual relations between man and birds. In: Luniak, M. (ed.), Urban Ecological Studies in Central and Eastern Europe. Ossolineum, Wroclaw, 122-130.

Juhász, L. (1983): Debrecen város ornithofaunájának faunisztikai és synökológiai vizsgálata. PhD Thesis, University of Debrecen.

Juhász, L. (1999): A Debreceni Köztemető természeti értékei. Debreceni Déri Múzeum Évkönyve, 1999: 7-29.

Juhász, L.-Kövér, L. -Gyüre P. (2009): The urbanization of the Hooded Crow (Corvus cornix L.) in Debrecen (Hungary). II. European Congress of Conservation Biology, Prague 2009, Book of Abstracts, 227.

Kalotás, Zs. (1995): Városlakó madarak. Természet világa: természettudományi közlöny, 126/2: 66-68.

Konstantinov, V.M. 1982. Numbers and some ecological features of synanthropic populations of the Corvidae under the conditions of intensive urbanization (European USSR). Zoologichesky Zhurnal, 61/12: 1837-1845

Korbut, V.V. 1996. The Moscow town's unique population of the hooded crow. Doklady Akademii Nauk, 348/1: 136-139.

Kulczycki, A. (1973): Nesting of the members of Corvidae in Poland. Acta Zool. Cracov., 18: 583-666.

Kövér, L.-Juhász, L. (2008): A dolmányos varjú (Corvus cornix L.) terjeszkedése Debrecenben. A Debreceni Déri Múzeum Évkönyve, Debrecen, 2008: 17-24

Loman, J. (1975): Nest distribution in a population of the Hooded Crow Corvus cornix. Ornis Scand., 6: 169-178.

Mazgajski, T.D.-Zmihorski, M.-Halba, R.-Wozniak, A. (2008): Long-term population trends of corvids wintering in urban parks in central Poland. Polish Journal of Ecology, 56/3: 521-526.

Moller, A.P. (1981): Nest site selection of hooded crows Corvus corone cornix in Denmark. Dansk Ornithologisk Forenings Tidsskrift, 75/12: 69-77.

Munkejord, A.-Hauge, F.-Folkedal, S.-Kvinnesland, A. (1985): Nest density, breeding habitat and reproductive output in a population of the Hooded Crow Corvus corone cornix on Karmoy, SW Norway. Fauna norv. Ser. C, Cinclus, 8: 1-8.

Parker, H. (1985): Effect of culling on population size in hooded crows Corvus corone cornix. Ornis Scandinavica, 16/4: 299-304.

Parlange, M. (1998): The city as ecosystem. Bioscience, 48: 581-585.

Roy, D.B.-Hill, M.O.-Rothery, P. (1999): Effects of urban land cover on the local species poll in Britain. Ecography, 22: 507-515.

Smedshaug, C.A.-Lund S.E.-Brekke, A.-Sonerud, G.A.-Rafoss, T. (2002): The importance of the farmland-forest edge for area use of breeding hooded crows as revelaed by radio telemetry. Ornis Fennica, 79/1: 1-13.

Sorace, A. (2001): Value to wildlife of urban-agricultural parks: A case study from Rome urban area. Environmental Management, 28/4: 547-560.

Tapfer, D. (1974): Dolmányos varjú (Corvus cornix) fészkelése Budapest belterületén 1973 tavaszán. Aquila, 80-81: 291.

Tapfer, D. (1978): A dolmányos varjú (Corvus cornix) további és rendszeres fészkelése Budapest VIII. kerületében. Madártani tájékoztató, 11-12: 39-41.

Tapfer, D. (1985): A dolmányos varjak (Corvus cornix) fészkelése Budapest belső kerületeiben. Madártani tájékoztató, 4-6: 55-56.

Tenovuo, R. 1963. Zur brutzeitlichen Biologie der Nebelkrähe (Corvus corone cornix L.) im äusseren Schärenhof Finnlands. Ann. Zool. Soc. 'Vanamo', 25: 1-147.

Ternovác, T. (1983): Dolmányos varjú (Corvus cornix) fészkelése földön. Madártani tájékoztató, 1-6: 48.

Ujhelyi, P. (ed.) (2005): Élővilág Enciklopédia - Kárpát-medence állatai. Kossuth kiadó, Budapest, 409-415.

Von Busche, G. (2001): Strong decline in the winter numbers of the Hooded Crow (Corvus corone cornix) in western SchleswigHolstein/NW-Germany. Vogelwarte, 41/1: 18-30. 
Vuorisalo, T.-Andersson, H.-Hugg, T.-Lahtinen, R.-Laaksonen, H.-Lehikonen E. (2003): Urban development from an avian perspective: Causes of hooded crow (Corvus corone cornix) urbanisation in two Finnish cities. Landscape and Urban Planning, 62/2: 69-87.

Withey, J.C.-Marzluff, J.M. (2005): Dispersal by juvenile American Crows (Corvus brachyrhynchos) influences population dynamics across a gradient of urbanization. Auk, 122/1: 205-221.

Zduniak, P.-Kuczynski, L. (2003): Breeding biology of the Hooded Crow Corvus corone cornix in Warta river valley (W Poland). Acta Ornithol. 38: 143-150. 